\title{
Apresentação
}

\section{Gestão cultural para a próxima década}

Esse dossiê foi pensado durante o início da pandemia da covid-19, quando estávamos ainda muito confusos com os acontecimentos e aguardávamos explicações para compreender o que ocorria com o mundo. Assistíamos a um momento tenso, cercado por incertezas e medos, vendo muitas pessoas perderem a vida e um conjunto de medidas restritivas sendo impostas na tentativa de conter esse novo vírus. Observávamos fronteiras sendo fechadas, eventos e atividades sendo remarcadas e uma transformação no cotidiano das pessoas que trouxe um novo normal, mediado pela tecnologia da comunicação e da informação e restrito de interações sociais. Em pouco tempo percebemos que esse novo normal duraria mais do que previsto, o que agravaria as crises econômicas, políticas e sociais que o país já vivenciava. Entendemos que a área da cultura, bem como outros setores, a exemplo do turismo, eventos, entre outros, que dependem da interação social, sofreriam grandes perdas e se transformariam drasticamente durante e após esse período. E, diante desse contexto, passamos a nos perguntar: Como deveremos pensar a gestão cultural para a próxima década? Quais aspectos deveremos levar em conta para compreender sua complexidade e seus processos de transformação e adaptação?

Desta forma, no primeiro semestre de 2021 lançamos a chamada pública para receber trabalhos para compor o dossiê Gestão cultural para a próxima década com o intuito de publicar uma edição que pudesse nos ajudar a compreender o que estava ocorrendo e nos orientar sobre as questões da gestão cultural no período pós-pandemia. Assim, este dossiê está dividido em temas variados que abordam a complexidade da gestão cultural e apresentam importantes discussões sobre seu futuro. A edição começa com um debate sobre o futuro da gestão cultural, das políticas culturais e da regulamentação dos setores culturais, apresentado por meio de quatro textos: "Gestão cultural nos próximos dez anos", no qual os autores trazem discussões sobre as exigências atuais da transversalidade da cultura e a ideia de uma sustentabilidade da cultura não reduzida à dimensão econômica; "Plano nacional de cultura e desenvolvimento: recuperando o planejamento das políticas culturais" e "Verba, evento e voto: a emenda parlamentar na gestão cultural, na produção de eventos e no cenário político do Brasil", que discutem o Plano Nacional de Cultura e o planejamento das políticas culturais atuais, bem como a questão do financiamento à cultura por meio das emendas parlamentares; e "Capacidades de coordinación interjurisdiccional de políticas culturales: aportes desde un estudio de caso al análisis de políticas públicas destinadas a la cultura en la Argentina contemporánea", que encerra a seção trazendo questões sobre as políticas culturais contemporâneas na Argentina.

Em seguida o dossiê continua com a seção "Setores culturais e criativos e a organização do trabalho", que apresenta, inicialmente, uma discussão sobre o campo de produção cultural e criativo na contemporaneidade, tendo como base conceitual as ideias de campo, habitus e capitais desenvolvidas 
por Pierre Bourdieu. Em seguida, os textos "Possibilidades com o processo criativo nas escolas de dança", "O papel da Ancine nas políticas públicas para o audiovisual brasileiro" e "Plano de Metas e Diretrizes para o Audiovisual: uma análise dos resultados das políticas públicas para o audiovisual no Brasil (2001-2015)" apresentam aspectos relativos a setores culturais específicos.

A seção seguinte, "Educação e formação profissional dos agentes culturais e criativos", reúne os textos: "Estudos em políticas culturais: passado, presente e futuro?", uma reflexão sobre o estado da arte das pesquisas acadêmicas na área; "Gestão e formação cultural no ensino superior: a criação da galeria virtual no contexto da pandemia da covid-19", que debate a formação superior em gestão cultural e as transformações ocasionadas pela pandemia; e "Formação e prática em gestão cultual: entre o tecnicismo e o engajamento", que aborda a relação entre a formação teórica e acadêmica e a formação prática e engajada dos agentes culturais. A quarta seção, "Territórios, identidades culturais e o desenvolvimento urbano" conta com os textos "Cultura e território aproximando saberes", que discute a relação entre cultura e território e aponta algumas articulações entre as políticas culturais e as práticas de produção do espaço urbano; "A cultura como valor na imagem de lugares: a influência cultural do Brasil", que analisa o posicionamento da imagem do Brasil em rankings internacionais e sua influência cultural no contexto sul-americano.

A quinta seção é destinada aos temas cultura, diversidade e direito cultural. O texto "Política de fomento à cultura e promoção da cidadania e direitos culturais" apresenta a articulação entre as noções de direitos culturais, em especial o direito de participação na vida cultural e sua relação com o conceito de cidadania para observar as políticas de fomento à cultura no Brasil. Em "Equipamentos culturais e diversidade cultural: perspectivas e desafios", os autores procuram discutir as perspectivas e desafios da gestão de equipamentos culturais e as diferentes narrativas usadas na promoção da diversidade cultural. Os textos "Artivismo de gênero e mediação sociocultural no Manifesto transpofágico de Renata Carvalho" e "A urgência de políticas públicas para artistas LGBTQ+ latino-americanos" discutem questões sobre a diversidade de gênero e os seus ativismos políticos na construção de políticas públicas de combate à violência contra a população LGBTQ+. A seção se encerra com o texto "Responsáveis por projeto financiado pelo Fundo Internacional da Diversidade Cultural contam suas impressões sobre a $13^{a}$ Sessão do Comitê Intergovernamental da Convenção Diversidade Cultural", que apresenta uma entrevista sobre o projeto Fortalecendo Redes Culturais.

A última seção é dedicada às questões sobre os impactos da pandemia no setor cultural. O texto "Being together, doing together and going forward together echoes from France's cultural third places in times of COVID-19" discute práticas de gestão cultural em espaços experimentais localizados no sul da França. Nele, as autoras apresentam os resultados de um estudo exploratório que identificou transformações nas dinâmicas de trabalho e gestão de espaços culturais durante a pandemia. "Os desafios dos setores criativo e cultural brasileiros durante e depois da pandemia da covid-19" propõe uma discussão sobre o enfrentamento das crises agravadas pela 
pandemia. Para isso, o texto apresenta os principais dados disponíveis que indicam a situação do setor cultural brasileiro no primeiro e segundo semestres de 2020 e discute a implementação da Lei Aldir Blanc como medida de emergencial para controlar a crise econômica do setor.

Para finalizar a seção, o texto "Produção e consumo cultural na pandemia da covid-19: novas perspectivas para um festival de teatro em Passos" reflete sobre a promoção e consumo durante a pandemia, dando destaque ao Festival Nacional de Teatro de Passo, que ocorreu em 2020.

Para fechar o dossiê, traduzimos trabalhos já publicados por dois pesquisadores que são referências nas áreas de cultura, mídia e comunicação, com o objetivo de torná-los acessíveis em língua portuguesa. "Capitalismo e a mídia: economia moral, bem-estar e capacidades", de David Hesmondhalgh, debate a relação entre mídia, cultura e capitalismo através de uma leitura crítica sobre o valor potencial da mídia na cultura. Já o texto "Perspectivas francófonas sobre indústrias criativas e economia criativa", de Philippe Bouquillion, apresenta algumas perspectivas francófonas sobre as indústrias criativas, destacando abordagens críticas e não críticas que contribuem para a compreensão da dinâmica da economia de bens simbólicos culturais. Assim, este dossiê reúne trabalhos nacionais e internacionais de pesquisadores e estudiosos da área, desenvolvidos durante o período de pandemia. O objetivo desta edição especial é trazer para o debate diferentes abordagens, temáticas e pontos de vista que nos orientem sobre a gestão cultural para a próxima década.

Boa leitura!

Profa. Dra. Karina Poli

Outubro de 2021

Docente do Centro de Estudos Latino-Americanos sobre Cultura e Comunicação (CELACC) 